\title{
Editorial: La Revista RIF en tiempos de pandemia
}

\author{
César Jiménez ${ }^{* 1}$ \\ ${ }^{1}$ Universidad Nacional Mayor de San Marcos, Lima, Perú
}

Lima, 26 de marzo de 2020

Con mucho esfuerzo y dedicación, nos complace en presentar el volumen 23, número 1 de la Revista de Investigación de Física (RIF), correspondiente a Enero-Junio de 2020. Desde su aparición en 1998, la revista RIF continúa editándose después de 23 años.

Estamos viviendo tiempos difíciles en todo el mundo a causa de la pandemia del Corona-virus, el cual ha causado la muerte de miles de personas a nivel mundial. En el Perú, hay a la fecha alrededor de 600 contagiados y 10 víctimas mortales.

Estamos confinados a una cuarentena hasta el 12 de abril con un toque de queda desde las 20:00 hasta las 05:00. Las clases escolares y universitarias han sido postergadas. El aparato productivo del Perú ha sido reducido a su mínima expresión: sólo trabaja el sector médico, venta y distribución de alimentos, telecomunicaciones y energía.

La idea de la cuarentena es reducir la velocidad de propagación del contagio del corona-virus, de tal manera que se evite el colapso del sistema hospitalario y de salud. Considerando que el sistema hospitalario peruano sólo cuenta con 400 Unidades de Cuidado Intensivo (UCI), lo que implicaría la atención simultanea de sólo 400 pacientes muy graves.

Los investigadores en Física no se mantienen al margen de esta guerra contra el corona-virus. Hay esfuerzos por desarrollar y aplicar nuevos materiales, así como el uso de la nanotecnología en esta guerra viral. Por su parte, los físicos médicos, están implementando prototipos para la implementación de respiradores artificiales y otros dispositivos para su uso en las UCI.
El impacto de esta pandemia en la investigación es enorme, debido al cierre de las universidades e institutos de investigación, muchos investigadores no podrían realizar sus estudios e investigaciones utilizando los equipos e infraestructura de la Universidad. Sin embargo, algunos investigadores pueden trabajar en forma remota desde sus hogares.

Dentro de toda esta coyuntura pandémica, sin embargo, es destacable el esfuerzo y trabajo de los autores e investigadores que han logrado publicar sus artículos en el presente volumen de la revista RIF (vol 23, No. 1), después del proceso de revisión por pares.

También cabe destacar el esfuerzo del equipo del Comité Editor por la compilación y programación de los archivos históricos en la página web de la revista RIF (https://fisica.unmsm.edu.pe/rif). Agradecemos el trabajo de los anteriores editores e investigadores que han hecho posible la continuidad de la revista RIF.

La revista RIF se encuentra indexada en el catálogo de Latindex 1.0. Sistema regional de información en línea para revistas científicas de América Latina, el Caribe, España y Portugal (http://latindex.org). Actualmente, estamos trabajando para aplicar a la indexación de Latindex 2.0, el cual es una versión actualizada, para lo cual se debe cumplir con un conjunto de requisitos mínimos.

Como una meta, esperamos lograr la indexación en el catálogo Latindex 2.0 a fines del 2020. Luego, la próxima meta será obtener la indexación en la base de datos Scielo, el cual es un poco más exigente que Latindex. Con el apoyo conjunto de autores, revisores y editores, cumpliremos esta meta.

\footnotetext{
*cjimenezt@unmsm.edu.pe
} 